\title{
The Power of an Agent to Bind His Principal-California and the Restatement
}

Fundamentai though the problem be, there exists, in the texts and case law on the subject, considerable confusion as to the bases of an agent's power to bind his principal. ${ }^{1}$ In many instances the confusion is not so much as to the decision ultimately reached as to the reasons therefor. Too often such terms as "authority," "apparent" or "ostensible" authority are seized upon as justifying the result without assigning to those words any clear meaning. These terms, in turn, are often reinforced by talk of "secret" or "private" instructions. To these are then added what, in this field, appears to serve the purpose of a convenient, if vague, catch-all-the doctrine of estoppel. If further ammunition is required to justify the result, the doctrine of ratification is invoked. The entire structure can then be capped by the often meaningless bromide to the effect that "where one of two innocent persons must suffer by the act of a third, he, by whose negligence it happened, must be the sufferer." 2 When this process of cumulation is finished the result defies analysis.

Certainly one of the highlights of the recently published Restatement of the Law of Agency is the logical and clean-cut classification of the bases of $A^{\prime} s$ power to bind $P .{ }^{4}$ It is the purpose of this paper to call this classification to the attention of the profession in California and in so doing to make, by way of comparison, some observations on the law of Cahfornia on this subject.

The appropriate starting point would appear to be the insistence of the Restatement on the distinction between "power" and "authority." : "Power" is therein defined as

"an ability on the part of a person to produce a change in a given legal relation by doing or not doing a given act." 8

$1 \mathrm{~A}$ verse in "the peculiar theme song of agency-the liability of the principal to third persons." Seavey, Book Review (1934) 47 Harv. L. REv. 728, 730.

2 CaI. Crv. Code $\$ 3543$.

3 Adopted and promulgated by the American Law Institute at Washington, D. C., May 4, 1933. American Law Institute Publishers, St. Paul.

4 The letters $P, A$ and $T$ will be used throughout as indicating principal, agent and third party, respectively.

5 This distinction is well recognized by modem writers on the subject. 1 Mechem, Agency (2d ed. 1914) \$712 et seq.; Trfantr, Agencx (Powell's ed. 1924) 37, 38; Corbin, Authority of an Agent-Definition (1925) 34 YALE L. J. 788; Seavey, The Rationale of Agency (1920) 29 YarE L. J. 859, 872. Seldom has the distinction been given any consideration in case law.

6 Restatement of teie Law of Agencx (Am. L. Inst. 1933) §6. 
"Authority is the power of the agent to affect the legal relations of the principal by acts done in accordance with the principal's manifestations of consent to him." 7

$A$, having authority, has a power which, as between himself and $P$, he is privileged to exercise. It is universally true that $P$ may be bound by the act of $A$ though the doing of the act by $A$ constitutes a breach of the fiduciary relation existing between $A$ and $P$. In such cases $P$ is bound because $A$ has a power or because $P$ is estopped. $A$ has no authority.

No California case has been found where the distinction between authority and power is stressed. The Civil $\mathrm{Code}^{8}$ defines "actual authority" in substantially the same terms as those used to define authority in the Restatement.9 "Power" is not defined in the Code and while the cases often make fugitive statements to the effect that "the agent has a power to bind his principal," 10 the words "power" and "authority" are used interchangeably and without any apparent thought of the distinction. ${ }^{11}$ There is but the vaguest suggestion in the Code that the framers had some notion that there may have been a difference..$^{12}$

The bases of $A^{\prime} s$ power to bind $P$ are set out in section 140 of the Restatement. ${ }^{13}$ It reads:

"The liability of the principal to a third person upon a transaction conducted by an agent, or the transfer of his interests by an agent, may be based upon the fact that:

(a) the agent was authorized;

(b) the agent was apparently authorized; or

(c) the agent had a power arising from the agency relationship and not dependent upon authority or apparent authority." 14

Let us examine these in order.

T Ibid. §7.

8 CAI. CIv. CODE \$2316: "Actual authority is such as a principal intentionally confers upon the agent, or intentionally, or by want of ordinary care, allows the agent to beheve himself to possess."

9 Note also ibid. \$2299: "An agency is actual when the agent is really employed by the principal."

10 E.g., Frasch v. London \& Lancashire Fire Ins. Co. (1931) 213 Cal. 219, 223, 2 P. (2d) 147, 148; Walker v. Kimball Fruit Co. (Cal. App. 1929) 283 Pac. 895, 897.

11 See, however, Torvend v. Patterson (1933) 76 Cal. App. Dec. 63, 67, 28 P. (2d) 413,415 . The problem was as to the liability of a retired partner for the act of the continuing partner. The court says: ". . . but until proper notice had been given to a creditor, he [the continuing partner] had the power although not the right, to subject the retiring partner to a liability."

12 Thus CAL. CIv. CODE $\$ 2320$ speaks of "the agent's power to disobey instructions." It may be of some significance that the remaining sections in this article of the Code are all phrased in terms of authority.

13 See also section 141 which deals with "liability based upon other than agency principles." These are not here considered.

14 One is led to suspect that the Restatement is indebted to Professor Seavey for this classification. See Seavey, loc. cit. supra note 5 . 
The power of an agent who is authorized to bind his principal is elementary and requires no discussion or citation of authority. It is equally elementary that in the absence of an agreement to the contrary, $P$ 's manifestation of consent to $A$ impliedly carries with it authority to do such things as usually accompany the act authorized, or such things as are reasonably necessary to effect the purpose of the authorization. ${ }^{15}$ So far at least there can be no quarrel between the views of the Restatement and the law in any common law or code jurisdiction. The situation is the same as though $P$, personally, had dealt with $T$.

Where $A$ oversteps his authority - when he violates his duty to $P-$ assuredly $P$ is often bound. Can the result be justified on contract or agency principles or must we rely on some non-agency doctrine such as estoppel? Too often the cases leave us in doubt. The answer of the Restatement is that the principles of contract and of agency are not exhausted when authority is exceeded and that recourse can, and should, be had to these principles before invoking the doctrine of estoppel.

This brings us to "apparent authority." The term is defined as:

". . . the power of an apparent agent to affect the legal relations of an apparent principal with respect to a third person by acts done in accordance with such principal's manifestations of consent to such third person that such agent shall act as his agent." 16

This definition deserves our particular attention because it gives a fixed meaning to a term which in the past has been used loosely and in a variety of ways. ${ }^{17}$ The essentials to the existence of this power in $A$ are, a manifestation, or representation, by $P$ to $T$ that $A$ is his $(P ' s)$ agent in this respect, and secondly, a dealing between $A$ and $T$ on this basis. This basis of power contemplates no question of any detriment to, or change of position on the part of, $T$. In other words, while it has in common with the doctrine of estoppel the representation and rehance it does not go all the way. The basis of $P$ 's liability is contractual and modern writers find no difficulty in squaring the results with ordinary contract principles. ${ }^{18}$ A Massachusetts case ${ }^{10}$ puts it in this language:

15 How far such "imphed" or "inferred" authority goes is a question of interpretation and is treated as such in the Restatement, sections 32 to 81 , incl. Compare with these Cax. Crv. CodE $\$ \$ 2319$ to 2326, incl.

16 Restatement \$8. See also section 159 which states $P$ 's liability for the acts of $A$ within his apparent authority.

${ }^{17}$ See 1 MrçäM, op. cit. supra note $5, \$ 720$ et seq.; cf. TIFFANY, op. cit. supra note 5 , at 63 .

${ }^{18}$ See Anson, Contracts (Corbin's 5th Am. ed. 1930) 8; Holinnd, JurisPRUDENCE (13th ed. 1924) 263; 1 MECHEM, op. cit. supra note 5,$8722 ; 1$ WIIIISTON, Contracts (1920) $§ \S 20,21$; Cook, Agency by Estoppel (1905) 5 CoL. L. 
"To lead a person reasonably to believe that you assent to an oral arrangement is to assent to it, wholly irrespective of fraud. Assent in the sense of the law is a matter of overt acts, not of inward unanimity in inotives, design or the interpretation of words."

The distinction between apparent authority and power resting on estoppel may become of importance. Thus, if the basis is contractual, $P$ is bound whether the transaction is executed or purely executory. So, if the transaction results in a contract, $T$ is bound, though he inost certainly is not estopped. ${ }^{20}$

Turning now to the California Civil Code and the California cases, we find the term "ostensible," rather than "apparent," authority used. A comparison of definitions convinces us that they are the saine. Ostensible authority is defined ${ }^{21}$ to be,

"such as the principal, intentionally or by want of ordinary care, causes or allows a third person to beheve the agent to possess."

Unfortunately for the cause of uniformity, however, a subsequent provision of the Code ${ }^{22}$ cuts down the liability of $P$ for the act of $A$, acting under

"a merely ostensible authority, to those persons who have in good faith, and without want of ordinary care, incurred a liability or parted with value, upon the faith thereof." 23

In other words, to be effective under this provision of the Civil Code, ostensible authority must be coupled with the additional element necessary to raise an estoppel. ${ }^{24} P$ 's liability in such case is not based upon

Rev. 36; Cook, Agency by Estoppel: A Reply (1906) 6 ibid. 34, 36; Seavey, op. cit. supra note 5, at 873. Cf. EwarT, EstopPex (1900) 473-4; Ewart, Agency by Estoppel (1905) 5 CoL. L. Rev. 354; Whittier, Restatement of Contracts and Mutual Assent (1929) 17 CaIIF. L. REv. 441.

19 O'Donnell v. Town of Clinton (1888) 145 Mass. 461, 14 N. E. 747.

${ }^{20} T$ 's liability to $P$ where $A$ acts under an apparent authority is provided for by the Restatement, section 292-and this apart from any question of ratification.

21 CAL. CIv. Code $\$ 2317$. Ibid. \$2300 defines "ostensible agency" as existing "when the principal intentionally, or by want of ordinary care, causes a third person to believe another to be his agent who is not really employed by him."

$22 \$ 2334$.

23 It may be noted that this section is phrased in terms of "ostensible authority" which is defined by section 231\%. It contains no reference to section 2300 which defines "ostensible agency." No case has been found calling attention to this fact and in many cases the three sections $(2300,2317$ and 2334) are read together. The terms "ostensible authority" and "ostensible agency" are used interchangeably in the following cases: Pacific Ready-Cut Homes v. Seeber (1928) 205 Cal. 690, 694, 272 Pac. 579, 581; Dollar v. The International Banking Corp. (1910) 13 Cal. App. 331, 340, 109 Pac. 499, 503; Robinson v. American Fish, etc., Co. (1911) 17 Cal. App. 212, 219, 119 Pac. 388, 391; Raleigh v. Lee (1914) 26 Cal. App. 229, 146 Pac. 696; Allen v. San Francisco, etc., Exchange (1922) 59 Cal. App. 93, 96, 210 Pac. 41, 42 ; Henry Cowell, etc., Co. v. Santa Cruz, etc., Bank (1927) 82 Cal. App. 519, 524, 255 Pac. 881, 882; Fairbanks v. Crump Irrig., etc., Co. (1930) 108 Cal. App. 197, 209, 291 Pac. 629, 634.

24 Cf. 1 CAL. JuRIs. (1921) 714: ". . . ostensible authority, at least for con- 
the existence of a contract. Presumably where $A$ acts under "a merely ostensible authority" $T$ is not liable to $P$ in the absence of a ratification by the latter. So presumably, $P$ is not liable to $T$ if the transaction is executory. 25

The California cases have with consistency construed the above sections as requiring an estoppel..$^{26}$ Language of the type which follows runs through them all:
"Ostensible authority rests upon the doctrine of estoppel, and its essen- tial elements are representation by the principal, justifiable reliance there- on by the third party, and change of position or injury resulting from such reliance." $2 \pi$
". . . the appellant $[T]$ is in no position to rely on any ostensible agency of the bank $[A]$ since he incurred no hability and parted with nothing of value on the faith thereof." 28

In California then, we must conclude that the second basis of power as set out in the Restatement classification, the apparent authority basis, is missing. To this extent certainly the power of $A$, in California, ${ }^{29}$ to bind $P$ rests upon a narrower foundation than the framers of

venience in discussion, may be divided into strict agency by estoppel and mere ostensible agency." The distinction here aimed at is not clear and subsequent pages of the same work fail to make it so. The New California Digest (McKinney's 1930) attempts a similar classification in vol. 1 , pp. 606 et seq.

See the distinction made by the Missouri court in Landau Grocery Co. v. Bank of Potosi (1930) 223 Mo. App. 1181, 26 S. W. (2d) 794, 795. "Apparent authority is not founded in negligence of the principal but in the conscious permission of acts beyond the power granted, whereas the rule of estoppel has its basis in the negligence of the principal in failing properly to supervise and control the affairs of the agent." One nnay question the usefulness of such a distinction.

25 Cf. Ewart, Agency by Estoppel, op. cit. supra note 18, at 363. Ewart's opinion appears to be that a mere dealing between $T$ and $A$ is a sufficient change of position on the part of $T$ to raise an estoppel where the other elements exist. Surely this is questionable. No case in point has been found.

26 Pacific Vinegar Works v. Smith (1907) 152 Cal. 507, 511, 93 Pac. 85, 86; Hansen v. Burford (1931) 212 Cal. 100, 112, 297 Pac. 908, 913; Herington v. Alta Planing Mill Co. (1914) 25 Cal. App. 620, 622, 144 Pac. 973, 974; Armstrong v. Barceloux (1917) 34 Cal. App. 433, 436, 167 Pac. 895, 897; Duerr v. Sloan (1919) 40 Cal. App. 653, 657, 181 Pac. 407, 408; Wellman v. Conroy (1920) 50 Cal. App. 141, 144, 194 Pac. 728, 729; Garcia \& Maggini Co. v. Colvin (1921) 53 Cal. App. 79, 84, 199 Pac. 1113, 1115; Zenos v. Britten-Cook Land, etc., Co. (1925) 75 Cal. App. 299, 242 Pac. 914; Pacific Acceptance Corp. v. Jones (1928) 95 Cal. App. 365, 369, 272 Pac. 1084, 1086; Earle v. De Besa (1930) 109 Cal. App. 619, 293 Pac. 885.

27 Ernst v. Searle (1933) 85 Cal. Dec. 633, 635, 22 P. (2d) 715, 716.

28 Van Buren v. Green (1932) 120 Cal. App. 461, 466, 7 P. (2d) 1079, 1081.

29 California is far from being alone in this respect. See Agency, 2 C. J. (1915) §§ 26-76. See also Note (1933) 1 ChICAGo L. Rev. 337 where Mr. Wolfberg questions "whether the restatenent's distinction between 'apparent authority" and" authority by estoppel is justified by either precedent or necessity." (Citmg cases.) 
the Restatement found to be consistent with principle and authority. The difference can be charged, or credited, to the clear provisions of the Code; provisions so clear that there appears to be no possibility of a different construction being put upon them by the courts.

The third basis of $A$ 's power under the classification of the Restatement is,

"a power arising from the agency relationship and not dependent upon

authority or apparent authority." 30

Later sections ${ }^{31}$ define, more particularly, such powers and the situations giving rise to them. The broadest of these ${ }^{32}$ reads:

"A general agent" for an undisclosed principal authorized to conduct transactions subjects his principal to liability for acts done on lis account, ${ }^{34}$ if usual or necessary in such transactions, although forbidden by the principal to do them." 35

The distinction between the power here stated to exist and that based upon apparent or ostensible authority is obvious. ${ }^{36}$ The latter terms of course involve a representation by $P$ to $T$ and activity on the basis thereof. ${ }^{37}$ In the cases contemplated by this section $T$ does not

$30 \S 140(c)$.

$31 \S \S 161-178,194-202$.

$32 \$ 194$.

33 One may question the desirability of perpetuating the distinction between general and special agents. See definition, Restatement, \$3, and CAx. Crv. CodE \$2297. "It is believed, however, that the distinction. [between general and special agents] as it is ordinarily drawn, is highly artificial and unsatisfactory, if not positively misleading, and that it might well be dispensed with." 1 MEcHEar, op. cit. supra note $5, \$ 738$.

The framers of the Restatement were fully aware of the desirability of doing away with the distinction but they were "restating" and bowed to tradition. See 7 Asr. L. Inst. Proceedings (1929) 240. It may be noted that while Car. Crv. CODE $\$ 2297$ draws the distinction, those code sections which deal with "Authority of Agents" (2304 to 2326) make no marked use of it.

34 See $\$ 199$ and the Reporter's Explanatory Notes to Tentative Draft No. 4 (1929) p. 27. These Notes, which will be referred to again, were published from time to time in support of the various Tentative Drafts. They were distributed among a limited number of members of the profession but are not published with the Restatement in its final form.

35 Restatement $\$ 302$ states the corresponding hability of $T$ to the undisclosed P. Cf. Oliphant, Book Review (1921) 19 MICE. L. REv. 358.

361 MECHEM, op. cit. supra note 5 , $\S \S 721,722,1767$, appears to sanction the phrase "apparent authority" in describing this power. ". . . So far as third persons are concerned, this apparent authority is included in the real authority." (\$722) This sounds strange in view of the learned writer's clear appreciation of the distinction between authority and power (\$712).

37 The California cases make it clear that where $T$ relies on the existence of an ostensible authority he must show that "he himself was cognizant of the facts which gave color to the alleged ostensible agency and caused him to believe that the person with whom lie dealt was acting in the capacity of an agent." Allen v. San Francisco, etc., Exchange, supra note 23 at 97, 210 Pac. at 42 . The same requirement is sometimes phrased: "... the party $[T]$ must believe that the agent 
even know that there is a principal, and clearly, in the absence of such knowledge, we cannot find the essentials of apparent authority whether that term is used $\mathrm{m}$ the Restatement sense or in the sense of an estoppel authority. ${ }^{38}$

The power here set out is not limited to the case of secret instructions, i.e., instructions which $P$ does not intend $A$ to communicate to $T{ }^{39}$ It arises whenever $T$ and $A$ act with reference to things ordinarily incidental to the authority conferred. $P$ ' $s$ liability must be predicated upon a power arising from the relationship. The situation seems somewhat analogous to the liability of a master for the torts of his servant while the latter is acting within the scope of his employment. ${ }^{40}$

The leading case of Watteau $v$. Fenzeick ${ }^{41}$ will serve to illustrate the principle. There the owner of a public house instructed his manager and apparent owner not to buy cigars. The owner, an undisclosed principal, was held liable for the price of the cigars. The case bas been criticized in England ${ }^{42}$ and in Canada ${ }^{43}$ but so far as the writer is

had authority, and such belief must be generated by some act or neglect of the person to be held." Hiarris v. San Diego Flume Co. (1891) 87 Cal. 526, 528, 25 Pac. 758, 759. Accord: Buckley v. Silverberg (1896) 113 Cal. 673, 679, 45 Pac. 804, 805; Gosliner v. Grangers' Bank (1899) 124 Cal. 225, 227, 56 Pac. 1029, 1030; Luft v. Arakelian (1917) 33 Cal. App. 463, 466, 165 Pac. 712, 713; Files v. Derderian (1919) 44 Cal. App. 256, 258, 186 Pac. 184, 135; Barton v. Studebaker (1920) 46 Cal. App. 707, 722, 189 Pac. 1025, 1034; McMurray v. Pacific, etc., Homes (1931) 111 Cal. App. 341, 345, 295 Pac. 542, 543. See also cases cited supra note 26. Cf. Hollywood Holding, etc., Corp. v. Oswald (1931) 119 Cal. App. 21, 5 P. (2d) 963 , where an undisclosed $P$ was held liable for the unauthorized act of his $A$ apparently on grounds of estoppel. The reasoming is dificult to follow. Accord: Hubbard v. Tenbrook (1889) 124 Pa. 291, 16 Atl. 817; Ernst v. Harrison (1904) 86 N. Y. Supp. 247.

38 But cf. Hollywood Holding, etc., Co. v. Oswald; Hubbard v. Tenbrook; Ernst v. Harrison, all supra note 37 .

39 "Secret instructions" are defined in the Restatement, in section 160, as those "intended not to be revealed." The commonest is of course a limitation upon the price. The term is often used loosely as indicating any limitation whereof $T$ is ignorant.

40 See ThFany, op. cit. supra note 5, at 256; Seavey, op. cit. supra note 5, at 885. In 2 Street, Foundations of Legat Liabirty (1906) 486 the author suggests: "It must always be borne in mind that the law of principal and agent is merely a branch of the broader doctrine of mastcr and servant, and a common principle underlies both." In cases where the fraud of $A$; in procuring a contract, is charged to $P$, the reason given is often ". . . he [A] was acting within the scope of his employment." Stockton, etc., Works v. Glens Falls Ins. Co. (1893) 98 Cal. 557, 576, 33 Pac. 633, 637.

41 (1893) 1 Q. B. 346.

42 Pollock, Note (1893) 9 L. Q. Rev. 111; cf. Encise Partnership Acr, 53 \& 54 Vicr. (1890) c. $39, \$ 5$, which was drafted by Sir Frederick Pollock; also of. Miles v. McIlwraith (1883) 8 App. Cas. 120 (a Privy Council case). Kinahan \& Co., Ltd. v. Parry (1911) $1 \mathrm{~K}$. B. 459, the latest English case in which the question was raised, is hardly satisfactory.

43 Becherer v. Asher (1896) 23 Ont. App. 202 draws what appears to be a 
aware it has been consistently followed in this country where the question has arisen. 44

If this power exists in the undisclosed principal cases, it should as well in the disclosed principal situation, if the latter cases cannot-and they often can-be based upon apparent authority or estoppel. Yet when we look to the section ${ }^{45}$ corresponding to the one just quoted, but dealing with the disclosed and partially disclosed principal, ${ }^{40}$ we find the statement of principle in these words:

"A general agent for a disclosed or partially disclosed principal subjects
his principal to liability for acts done on his account which usually accom-
pany or are incidental to transactions which he is authorized to conduct if,
although they are forbidden by the principal, the other party reasonably
beheves that the agent is authorized to do them and has no notice 47 that
the agent is not so authorized." 48

The differences in phraseology are as plain as the reasons therefor are obscure. Particularly deserving of attention are the words, "the other party reasonably believes the agent is authorized to do them." The presence of these words raises two problems: first, the difficulty of reconciliation with section 194; second, the difficulty of distinguishing between the power here stated and that based upon apparent authority.

The comments and illustrations under the present section and those under that dealing with the undisclosed principal situation give no hint that any different statement of principle was intended. In fact they seem to proceed consciously on what appears to be the perfectly reasonable assumption that the same principle underlies both sections. ${ }^{49}$

If we go back of the Restatement as it appears in its final form, we get no further assistance in the solution of this problem. Thus in the Reporter's Explanatory Notes to Tentative Draft No. 4 of the Restatement ${ }^{50}$ where both sections are dealt with, no reference is made to the differences in phraseology and the whole tenor of the Notes is that

hair-splitting distinction to reach a result favorable to $P$. In McLaughlin v. Gentles (1919) 46 Ont. L. R. 477, 51 D. L. R. 383, the Ontario Court of Appeals refused to follow Watteau v. Fenwick, supra note 41 , preferring the reasoning of Miles v. Mcllwraith, supra note 42.

44 Collentine v. Johnson (1926) 203 Iowa 109,202 N. W. 535, 208 N. W. 318; Bond v. O'Donnell (1928) 205 Iowa 902, 218 N. W. 898; Maxcy Mfg. Co. v. Burnham (1897) 89 Me. 538, 36 Atl. 1003; Brooks v. Shaw (1908) 197 Mass. 376, 84 N. E. 110; Dean v. Vice (1919) 234 Mass. 13, 124 N. E. 673; McCracken v. Hamburger (1891) $139 \mathrm{~Pa} .326,20$ Atl. 1051. See also cases reaching the same result via estoppel, suprat note 37 .

45 Restatement, \$161.

- 46 Defined in Restatement, \$4. In the general case law no clear distinction between the partially disclosed and undisclosed principal is recognized.

47 "Notice" is defined in $\$ 9$.

$48 \$ 292$ states the liability of $T$ to $P$ under like circumstances.

40 See particularly Comment (b) to \$194: "The comment on section 161 is applicable."

50 P. 8, et seq. 
the principle of the undisclosed principal cases applies equally to the cases provided for by section 161.51 The Reporter's discussion of this part of the Restatement before the American Law Institute ${ }^{52}$ is to the same effect. No distinction is found in the modern writings on agency. ${ }^{53}$

It seems equally clear from such discussion as preceded the final adoption of the section that the power stated therein was not intended to be merely coextensive with that based upon apparent authority. ${ }^{64}$ The existence of the section itself would indicate that it was intended to add another basis of power.

The writer feels that the inclusion in section 161 of the words under consideration was unfortunate and that they might well have been omitted. But inasmuch as they are included, it would seem that in the

51 The following citations are taken from the Explanatory Notes to Tentative Draft No. 4. They deal with disclosed and partially disclosed principal cases. Butler v. Maples (1869) 9 Wall. (76 U. S.) 766; Three States Lumber Co. v. Moore (1918) 132 Ark. 371, 201 S. W. 508; Smith v. Jessup \& Moore (Del. 1848) 5 Har. 121; Thurber v. Anderson (1878) $88 \mathrm{Ill}$. 167; Crain v. Nat. Bank (1885) 114 Ill. 516, 2 N. E. 486 ; Cruzan v. Smith (1872) 41 Ind. 288; Talmage v. Bierhause (1885) 103 Ind. 270, 2 N. E. 716; Gaar, Scott \& Co. v. Rose (1891) 3 Ind. App. 269, 29 N. E. 616; Lewis v. Chapin (1928) 263 Mass. 168, 160 N. E. 786; Potter v. Springfield Mill. Co. (1897) 75 Miss. 532, 23 So. 259; Hatch v. Taylor (1840) 10 N. H. 538; Towle v. Leavitt (1851) 23 N. H. 360; Corklite Co. v. Rell Realty Corp. (1928) 249 N. Y. 1, 162 N. E. 565 ; Wilder v. Hinckley Fibre Co. (1923) 97 Vt. 45, 122 Atl. 428; North Eastern Nash Auto Co. v. Bartlett (1927) 109 Vt. 246, 136 Atl. 697; Bentley v. Doggett (1881) 51 Wis. 224, 8 N. W. 155; Smith v. McGuire (1858) 3 H. \& N. 554.

At page 13 of the Explanatory Notes the Reporter, Professor Seavey, says: "The following cases dealing with the undisclosed principal are also inserted as supporting the rule of this Section [161], as in each case the act was done by a general agent in the scope of bis employment and of course without knowledge by the other party as to the existence of an authority to affect the principal." There follows a list of authorities supporting the statement of section 194. See supra note 44.

527 Aju. L. Inst. Proceedings (1929) 238 et seq.

53 See 1 MeснEM, op. cit. supra note 5, \$\$720 et seq., 1767, 1768; ThFaNY, op. cit. supra note 5, at 255 et seq.; Seavey, op. cit. supra note 5, at 877 et seq.

54 In 7 Axr. L. INST. PRoceednas 238, Mr. Seavey is reported as saying: "It has been stated in many cases, or in some at least, that a principal is not bound by the conduct of an agent in the making of a contract unless the agent was authorized or apparently authorized. This statement in Section 385 [section 161 in the Restatement as published] goes beyond this." In the Explanatory Notes to Tentative Draft No. 4 at page 7 et seq., in discussing Smith v. McGuire, supra note 51, Mr. Seavey says: "It did not appear and seems not to have been material in the case that the third person knew of the holding-out by the principal. This prevents the case from being one of apparent authority." And in Comment (b) to section 161 we read the following: "The rule stated in this section applies to the case where there is apparent authority, but includes also cases where there is no apparent authority. Thus the principal may be liable upon a contract made by a general agent doing a forbidden act usually within the authority of such agents, although neither principal nor agent has revealed to the third person the extent of the agent's authority." 
interests of consistency and in order that the section may conform to the authorities upon which it is based, the words must be construed as requiring of $T$ nothing inore than good faith, or, in the alternative, they must be construed to mean that $T$ 's belief would be reasonable, though resting solely on $A^{\prime} s$ representations as to his authority, ${ }^{55}$ often evidenced only by the doing of the prohibited act. The reader may well feel that such an interpretation twists the ordinary meaning of the expression "reasonably beheves." Discussion of the problem by courts and writers should be of interest.

We turn to the California law and curiously enough no case directly in point has been found. The emphasis placed upon estoppel im connection with ostensible authority would lead one rather to assunie that apart from either authority or estoppel $P$ is not bound. This would, of course, rule out powers arising simply froin the agency relation.

Many cases discuss the effect of secret or private instructions ${ }^{56}$ and the following statements are typical:

"The principal cannot by private communications with his agent limit

the authority he allows the agent to assume." 57

". . a limitation upon the powers of a general agent is not binding upon third persons dealing with him as such unless called to their attention." 58

But in cases using this kind of language it appears that the result, where $P$ is held, can be explained either on an estoppel basis or on the grounds of an actual, though implied authority. In neither case is the problem squarely presented.

Superficially section $2319(1)$ of the Civil Code bears a close resemblance to section 161 of the Restatement as set out above. The former provides that an agent has authority,

"to do everything necessary or proper and usual, in the ordinary course

of business, for affecting the purpose of his agency." 59

55 This would seem inplied in Comment (c) to section 161 where we read: "A principal is subject to liability if his general agent to sell gives a customary but forhidden warranty to a third person who does not know that it is customary to warrant but believes from what the agent tells him that the agent has authority to give the warranty." See also Illustration 1 to this section.

56 Hoskins v. Swain (1882) 61 Cal. 339; Heald v. Hendy (1891) 89 Cal. 632, 27 Pac. 67; Whitton v. Sullivan (1892) 96 Cal. 480, 482, 31 Pac. 1115; Browning v. McNear (1910) 158 Cal. 525, 529, 111 Pac. 541, 542; Leavens \& Pinkham v. McKevitt (1912) 164 Cal. 242, 128 Pac. 399; Robinson v. American Fish, etc., Co., supra note 23, at 219, 119 Pac. at 390; Rattray v. Wickersheim Co. (1918) 36 Cal. App. 253, 258, 171 Pac. 964, 966; Henry Cowell, etc., Co. v. Santa Cruz, etc., Bank, supra note 23; Burns v. McCain (1930) 107 Cal. App. 291, 290 Pac. 623; Fairbanks v. Crump Irrig., etc., Co., supra note 23, at 209, 291 Pac. at 634; Van Buren v. Green (1932) 120 Cal. App. 461, 7 P. (2d) 1079. $83,85$.

57 Eddy v. American Amusement Co. (1913) 21 Cal. App. 487, 490, 132 Pac.

58 Thomas v. Fursman (1918) 39 Cal. App. 278, 284, 178 Pac. 870, 873.

59 See also CaL. Crv. Code $\S \S 2323$ to 2326 which appear to be specific applications of the general $\$ 2319(1)$. 
This section is usually referred to in the cases which speak of private instructions. Bearing in mind that it is phrased in terms of authority and bearing in mind the Code definition of actual authority, it would appear that section 2319 (1) can only come into play in the absence of an agreement between $P$ and $A$ to limit these acts which are "proper and usual in the ordinary course of business for affecting the purpose of the agency." In other words, section 2319(1) is only a declaration of an actual, though implied, authority to do incidental acts. If there is a prohibition from $P$ to $A$ as to these acts $A$ has no authority and section 2319 (1) does not affect the case though the doctrine of estoppel may. In a recent case, the supreme court says: "An agent also has such authority as is given by statute (Cal. Civ. Code secs. 2304 et seq.) unless deprived thereof by his principal." 60

This conclusion as to the proper construction to be placed on section 2319 (1) appears inevitable when read with the section which immediately precedes it and which provides:

\section{"Every agent has actually such authority as is defined by this title, unless specially deprived thereof by his principal, and has even then such authority ostensibly, except as to persons who have actual or constructive notice of the restriction upon his authority." 61}

Were it not for the presence of this section it would be arguable that the incidental authority section, $2319(1)$, should be construed as qualifying the Code definition of actual authority. ${ }^{02}$ Under this construction by reading the two sections together the result would be: $A$ has such authority as $P$ confers upon him and in addition thereto, despite restrictions, he has, as to third persons ignorant of such restrictions, authority to do such things as are normally incidental to the authority granted. ${ }^{63}$ The result would agree with the Restatement, as above construed, though at the cost of the anomaly of $A$ having an authority as to $T$ though none exists as between himself and $P$. Section 2318 appears conclusively to forestall this method of reconciliation. If $A$ is deprived of authority such as is granted by section $2319(1), T$ must rely on ostensible authority with the California implications of that term.

The same section (2318) closes an even less plausible avenue of effecting an agreement which would be reached by construing the word "authority" in such a section as $2319(1)$ as meaning "power." The difficulty of such a construction is not lessened by the appearance of

60 Ernst v. Searle, supra note 27 at 635,22 P. (2d) at 716. (Italics added.)

$61 \$ 2318$.

62 \$2316, supra note 8.

63 See supra note 36. 
the word "power" in the very next section" of the Code. This would seem to suggest that the framers of the Code had some notion, vague and inaccurate though it might have been, of the distinction between power and authority. The inference that they meant "authority" when they used the word is strengthened.

It seems clear then that as the law stands at present the only true agency basis of power recognized in California is that which rests upon authority. Unless such a basis is present $T$, to hold $P$, must rely on the doctrine of estoppel, which of course is not based on agency principles. This result is accounted for by the archaic provisions of the Civil Code which were drafted in the heyday of the subjective theory of contracts and during a period when the distinction between power and authority was not appreciated. Certainly the law of agency had reached no degree of maturity by the middle of the last century. Its codification, to the extent that it was codified by the Field Code, served to crystallize immature law and crainp growth, as premature codification inevitably does.

If the bases of $A$ 's power as set out in the Restatement are sound, and it is submitted that, as construed above, they are, both on principle and the authority of the general case law, it might be well to bring the Civil Code of California into line in the small field discussed.

Sigvald Nielson.

SCHOOI OF LAw,

STANFORD UNIVERSITY.

64 $\$ 2320$ (dealing with an "agent's power to disobey instructions"). Did the framers not mean authority to disobey? $C$ f. Restatement, $\$ 47$, raising an "inference of authority to act in an emergency." 